\title{
Observation of Polar Stratospheric Clouds down to the Mediterranean coast
}

\author{
P. Keckhut ${ }^{1}$, Ch. David ${ }^{1}$, M. Marchand ${ }^{1}$, S. Bekki ${ }^{1}$, J. Jumelet ${ }^{1}$, A. Hauchecorne ${ }^{1}$, and M. Höpfner ${ }^{2}$ \\ ${ }^{1}$ Service d'Aéronomie, Institut Pierre Simon Laplace, B.P. 3, 91371, Verrières-le-Buisson, France \\ ${ }^{2}$ Forschungszentrum Karlsruhe, Institut für Meteorologie und Klimaforschung, Karlsruhe, Germany
}

Received: 8 March 2007 - Published in Atmos. Chem. Phys. Discuss.: 15 May 2007

Revised: 5 October 2007 - Accepted: 6 October 2007 - Published: 12 October 2007

\begin{abstract}
A Polar Stratospheric Cloud (PSC) was detected for the first time in January 2006 over Southern Europe after 25 years of systematic lidar observations. This cloud was observed while the polar vortex was highly distorted during the initial phase of a major stratospheric warming. Very cold stratospheric temperatures $(<190 \mathrm{~K})$ centred over the Northern-Western Europe were reported, extending down to the South of France where lidar observations were performed. CTM (Chemical Transport Model) investigations show that this event led to a significant direct ozone destruction (35 ppb/day), within and outside the vortex as chlorine activated air masses were moved to sunlight regions allowing ozone destruction. If such exceptional events of midlatitudes PSCs were to become frequent in the future, they should not compromise the ozone recovery because their effect appears to be limited temporally and spatially. More importantly, these events might tend to be associated with the initial phase of a stratospheric warming that results into a weakening and warming of the polar vortex and hence into a reduced probability occurrence of PSC temperatures during the rest of the winter.
\end{abstract}

\section{Introduction}

Following the Montreal Protocol (1987) and its successive amendments, production and emissions of the anthropogenic halogenated ozone-depleting gases have been strongly regulated (WMO, 1999). So, while the stratospheric abundance of these gases is decreasing slowly in the stratosphere, the "ozone layer" is expected to recover, all other factors remaining constant (Chipperfield et al., 2005; Austin and Wilson, 2006). The main uncertainty about the ozone evolution lies with simultaneous climate changes. On a global scale, strato-

Correspondence to: P. Keckhut

(keckhut@aerov.jussieu.fr) spheric temperatures are expected to cool down due to ozone depletion, but also to the increase in the concentrations of greenhouse gases. Such findings are already reported and simulated (Ramaswamy et al., 2001), although trends are less clear at high latitudes due to a larger natural variability and potential dynamical feedback. Nearly twenty years after the signing of the Montreal Protocol, the timing and extent of the ozone recovery is uncertain. A major link between climate conditions and ozone loss originates from Polar Stratospheric Clouds (PSC) that form in a cold stratosphere and results in ozone destruction through heterogeneous chemical reactions (Crutzen and Arnold, 1986). PSCs are responsible for the conversion of the halogen reservoir species into active ozone destroying radicals $(\mathrm{Cl}, \mathrm{ClO}, \mathrm{BrO})$. They usually form within the polar vortex during wintertime. The frequency and the altitude of occurrence of these clouds can be monitored by lidar operating continuously in polar regions, such as those deployed within the frame of the Network for the Detection of Atmospheric Composition Changes (NDACC).

Here, we report the first detection of a PSC at mid-latitudes over southern Europe, in January 2006, after 25 years of systematic lidar measurements. The purpose of this investigation consists in describing such an unusual PSC event and quantifying associated ozone lost that has occurred at a location where sun irradiance allows to induce a direct ozone heterogeneous-chemistry depletion. However, while ozone profiles are obtained at the same site around twice a week, the sporadic nature of the event, the large dynamic induced ozone fluctuations as well as the measurement continuity do not allow an accurate estimate of the ozone lost associated with this PSC events. While ozone depletion associated with the presence of PSC has not to be proved, it is interesting to quantify the expected ozone lost to be able to estimate the contribution of such low-latitude PSC event on the total polar ozone depletion and its potential impact on the ozone recovery. To perform such an estimate, a numerical simulation was performed using a Chemistry-Transport Model that was

Published by Copernicus Publications on behalf of the European Geosciences Union. 

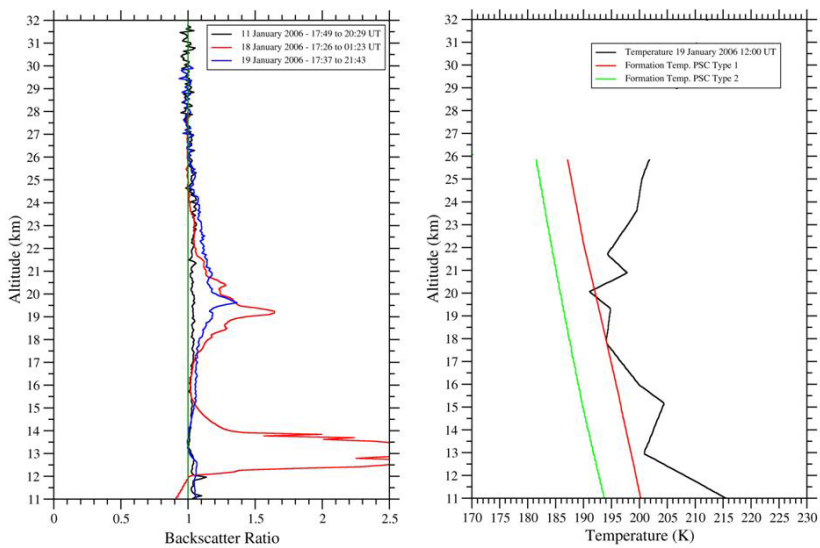

Fig. 1. Lidar backscatter ratio and collocated radiosonde temperature profile. (a) Lidar backscatter ratio profiles measured at the Observatory of Haute-Provence on 11 January 2006 showing typical background aerosol signature and on 18 and 19 January.

already intensively used to quantify polar ozone depletion. In the second section, these lidar observations are described. Then, the background conditions are analysed in the third section. In a fourth section, the impact of this PSC event on ozone is evaluated using a chemistry-transport model. Finally, the formation conditions of this cloud and the potential consequences on ozone recovery of this type of event are discussed.

\section{Lidar observations}

The principle of the lidar is similar to the radar, except that optical wavelengths are used. Remote sensing of particles with lidar with only one detection channel gives access to high-resolution vertical profiles of their optical properties but not to their microphysical characteristics. The wavelength has to be chosen outside the main absorption bands of the atmospheric constituents. The traditional quantity derived from the combined Mie and Rayleigh components of the lidar signal is the backscatter ratio, which is the ratio of the total backscatter coefficient (light scattered at $180^{\circ}$ of the emission beam by both molecules and particles) to the molecular backscattered coefficient (light scattered at $180^{\circ}$ by molecules only). Thus, a backscatter ratio greater than one indicates the presence of particles (Russell et al., 1979) and its amplitude can be related to the composition and the size distribution of the particles.

Two major classes of particles are observed in the stratosphere: sulfuric acid aerosols, present at all latitudes throughout the year (background aerosols) (Junge et al., 1961; Turco et al., 1982) and periodically enhanced by volcanic eruptions, and Polar Stratospheric Clouds (PSC) which form in polar regions, during both austral and boreal winters, when stratospheric temperatures fall below $195 \mathrm{~K}$ typically
(McCormick et al., 1982; Turco et al., 1989). From previous lidar observations, the expected range of backscatter ratio values for the different PSC types (nitric acid containing clouds are Type 1 and water ice clouds are Type 2) is known (Poole and McCormick, 1988; Toon et al., 1990; David et al., 1998).

Backscatter lidar observations of stratospheric particles are conducted over the Observatory of Haute-Provence (OHP $-44^{\circ} \mathrm{N}, 5^{\circ} \mathrm{E}$ ) since the 1980 's, within the frame of the NDACC. The operating wavelength is $532 \mathrm{~nm}$ and backscatter ratio profiles between about 8 and $35 \mathrm{~km}$ are acquired 3 to 4 times a week, for several hours during nighttime and averaged to obtain a daily profile. The uncertainties never exceed $7 \%$ on average (Chazette et al., 1995). Beyond stratospheric particles measurements, the instrument is also used to study cirrus clouds (Goldfarb et al., 2000; Keckhut et al., 2006).

In January 2006, we found for the first time, the occurrence of typical PSC signals on lidar observations at the OHP. On Fig. 1, backscatter ratio profiles obtained on 18 January and 19 January 2006 are compared to a typical background aerosols profile acquired on 11 January 2006. The backscatter ratio signatures detected on 18 January and 19 January were clearly different from the background aerosols signature. The peak values of the backscatter ratio were located at $19.2 \mathrm{~km}$ and $19.6 \mathrm{~km}$ respectively, which is too high for a cirrus cloud (besides, a cirrus was also observed at $13 \mathrm{~km}$ on 18 January). The maximum of backscatter ratio on both days were about 1.5 and the vertical extension of the clouds reached more $5 \mathrm{~km}$ (between roughly 17 and $22-24 \mathrm{~km})$. There is no depolarization measurements to inform us about the cloud phase. However, the cloud characteristics (small backscatter ratio, cloud geometrical depth, temperature conditions) suggest that the observed clouds are Type 1 PSCs (David et al., 1997; David et al., 1998), probably Type $1 \mathrm{~b}$ composed of liquid ternary solution droplets of $\mathrm{H}_{2} \mathrm{SO}_{4} / \mathrm{HNO}_{3} / \mathrm{H}_{2} \mathrm{O}$ (Tabazadeh et al., 1994; Carslaw et al., 1994). Yet, if Type 2 PSCs can definitely be excluded, only depolarisation could allow us to distinguish definitely between Type Ia and Type $1 \mathrm{~b}$ in our observations. This ground-based Lidar detection of Polar Stratospheric Clouds at mid-latitudes have been confirmed by global measurements with the Michelson Interferometer for Passive Atmospheric Sounding (MIPAS) on Envisat. The mid-infrared limb-emission measurements had already been analyzed during the Antarctic winter 2003 with respect to PSC composition with coincident Lidar observations from Mc-Murdo (Hopfner et al., 2006). The top heights of the PSCs can be derived from MIPAS observations for the days 18 to 21 January 2006 (Fig. 2). MIPAS observations indicate PSC top altitudes between 18 and $25 \mathrm{~km}$. On 18 and 19 January PSCs are located at latitudes of $40-60^{\circ} \mathrm{N}$, at longitudes of $10^{\circ} \mathrm{W}$ on 18 January and $0^{\circ}$ on 19 January, respectively. On the following two days these PSCs have vanished. The observed PSC area correlate best with Type 1b PSC temperature threshold. 
Stratospheric clouds have already been detected over the northern Europe. One of the PSC event observed in the lowest latitude in the northern hemisphere (Vaughan and Wareing, 2004) was detected on 10-11 January 2003. This cloud was observed above Aberystwyth $\left(52,4^{\circ} \mathrm{N}, 4,06^{\circ} \mathrm{W}\right)$, $8^{\circ}$ northward of OHP. Some PSCs were also detected above Scotland (Carter and Bridge, 1978). However, the most probably southern NH-PSC, was observed in March 1996. It was detected above England in 3-4 March 1996 by the satellite-borne HaLogen Occultation Experiment instrument (Hervig, 1999) and also above Berlin $\left(52^{\circ} \mathrm{N}\right)$ and Garmisch $\left(47.5^{\circ} \mathrm{N}\right)(\mathrm{C}$. Wedekind, Dissertation, FU Berlin, 1997). Note also, that a cloud has already been observed in the lower stratosphere over OHP, but the backward trajectories calculations indicated that the cloud was formed within a laminae originating from the moist subtropical troposphere and moving isentropically into the lower stratosphere; It exhibited a sporadic signature at $14 \mathrm{~km}$, nearly $3 \mathrm{~km}$ above the thermal tropopause (Keckhut et al., 2005).

\section{Background conditions}

PTU sondes are launched daily at 12:00 UT by the French Meteorological Institute, Météo-France, at Nîmes (about $100 \mathrm{~km}$ west of OHP). The temperature profile measured on 19 January is also shown on Fig. 1, together with the calculated formation temperatures for Type 1 (Hanson and Mauersberger, 1988) and Type 2 PSC (Murray, 1967), for 10 ppbv $\mathrm{HNO}_{3}$ and 5 ppmv water vapor. Stratospheric temperatures between 17 and $20 \mathrm{~km}$ are close to Type 1 PSC formation temperature. Further north, at Lyon (around $200 \mathrm{~km}$ north of OHP), temperatures recorded by the radiosonde on 19 January at noon at the cloud level are even colder (189 K). These in situ temperature observations are in good agreement with the European meteorological analyses shown on Fig. 3. The vortex was highly distorted and its coldest part was centred over the North-Western part of Europe with temperatures lower than $190 \mathrm{~K}$ on the $475 \mathrm{~K}$ isentropic level, extending down to the South of France where lidar observations were conducted.

During the cloud event reported here, the vortex at the cloud altitude was very disturbed with a very large area of polar air extending over central Europe (see Fig. 3b). Note that the temperatures are also low on the edge and outside of the vortex, down to the west coast of France and to the Iberic peninsula. Air mass backward trajectories clusters are calculated using the FLEXPART model forced by the ECMWF meteorological analyses (Stohl, 1998). The air parcels corresponding to the PSC layer detected over OHP on 18 and 19 January are advected backwards in time from OHP and dispersed during several days. These calculations clearly show that air masses are originating from the coldest area. This PSC event corresponds to a major mid-winter stratospheric warming with a large displacement of the vortex over Eu-
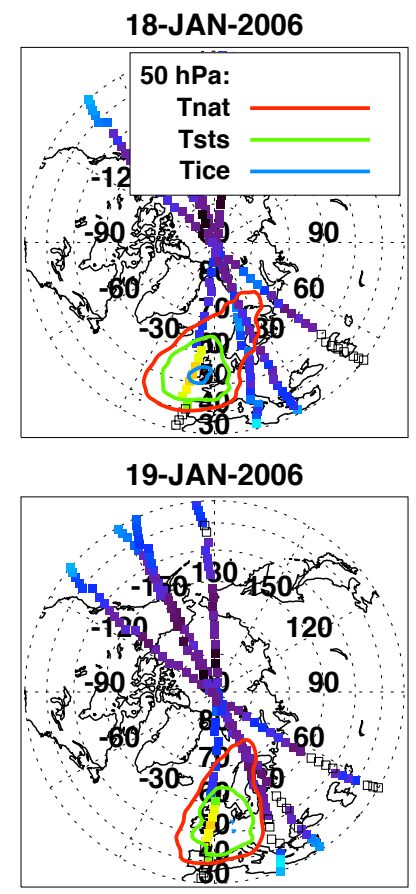

20-JAN-2006

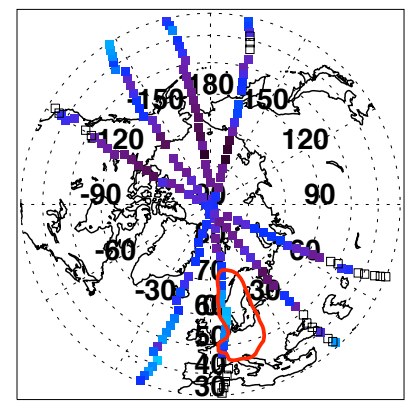

21-JAN-2006

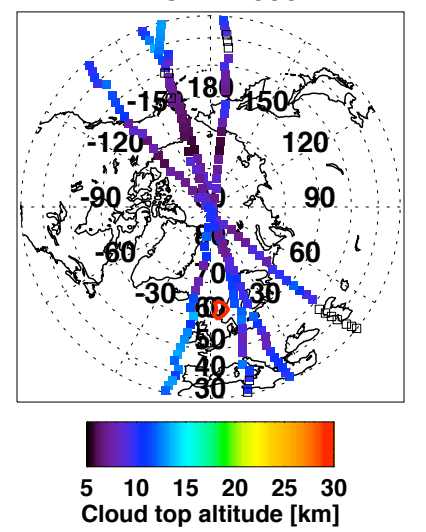

Fig. 2. PSC top heights derived from MIPAS/Envisat observations on 18 to 21 January 2006. PSCs appear as green, yellow and orange squares indicating PSC top altitudes between 18 and $25 \mathrm{~km}$. Red, green and blue contour lines indicate PSC threshold temperatures at $50 \mathrm{hPa}$ as deduced from ECMWF analyses for respectively Nitric Acid Trihydrate (NAT), Supercooled Ternary Solution (STS) and ice. 

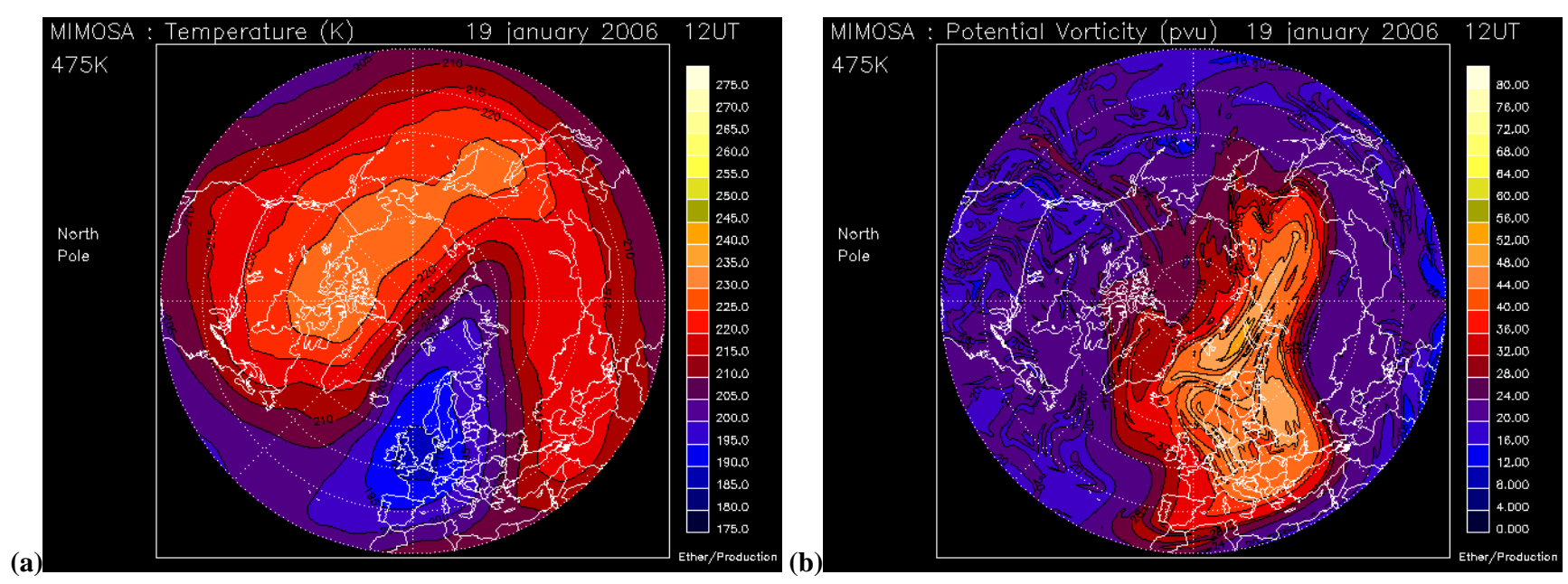

Fig. 3. Maps of the temperature and Vorticity on 19 January at 12:00 UT. Temperatures are given in K (a) and Potential Vorticity is given in PVU (b) on the $475 \mathrm{~K}$ isentropic level. High-resolution potential vorticity is calculated with the advection model MIMOSA (Hauchecorne et al., 2002) driven by ECMWF (European Centre for Medium-Range Weather Forecast) wind field, while temperature field are also deduced from ECMWF analysis. The edge of the polar vortex edge is usually defined as the region of maximum PV gradients that correspond approximately to the 36 PVU contour on the figure. Maps are available on http://ether.ipsl.jussieu.fr/ for previous and past days.

rope and Siberia, known as a Canadian warming (Charlton and Polvani, 2005). The considered air masses remain on the same potential temperature level of about $450 \mathrm{~K}$ during transit indicating isentropic transport around $10 \mathrm{~km}$ above the tropopause, well into the stratosphere. When the air masses cross the latitude of $70^{\circ} \mathrm{N}$ in the evening of 16 January, their temperature is $200 \mathrm{~K}$. Then, on 17 January the temperature of the air masses decreases to a minimum value of $188 \mathrm{~K}$ and then increases slowly up to $190 \mathrm{~K}$ before detection above OHP. Displacements of the Arctic polar vortex above OHP have already been reported (Godin et al., 2002; Marchand et al., 2003). However, they have never been associated with cloud detection with the OHP lidar, though it has been operating several hours a night when the sky is clear (that is, about 200 nights/year) for about 25 years. When the vortex is dynamically disturbed, polar air can reach the OHP site under the form of either polar filaments or vortex excursion. Yet, disturbed vortices that are usually detected over OHP are warmer because the phenomena occurs either during a disturbed winter associated with early stratospheric warming or in late winter. In both cases, the vortex is warmer and temperatures in the mid-latitude stratosphere over OHP remain above temperature threshold for PSC formation. In contrast, a cold vortex is very stable and, in this case, polar air excursions above mid-latitude regions are rare.

\section{Potential impact on ozone chemistry}

A Chemistry Transport Model (CTM) is used to estimate the ozone depletion associated with this PSC event. The 3dimensional high-resolution chemical transport model called
Modèle Isentropique de transport Méso-échelle de l'Ozone Stratosphérique par Advection avec CHImie (MIMOSACHIM) was developed to study the role of small-scale transport processes in determining the chemical composition of the stratosphere (Marchand et al., 2003). The model uses an isentropic vertical coordinate and is forced by temperature, pressure and wind fields provided by ECMWF daily analysis. The chemical scheme is taken from the REPROBUS CTM (Lefèvre et al., 1994). This model includes 41 chemical species or families and a heterogeneous chemistry module, which takes into account liquid super-cooled aerosols, and ice particles. NAT (Nitric Acid Trihydrate) PSCs are neglected in this simulation because the magnitude of the measured backscatter suggests that the PSC over OHP is likely to be liquid. Heterogeneous reaction rates are calculated explicitly, as a function of the PSC surface areas, assuming a radius of 1 and $10 \mathrm{~mm}$ respectively for Type I and Type II. PSC sedimentation is also taken into account.

For the period of interest (from 18 January to 20 January), the CTM predicts a very large PSC area centred over the North-Western part of Europe (Fig. 4). The model-calculated PSC surface area available for heterogeneous chemistry is about $15.10^{-9} \mathrm{~cm}^{2} / \mathrm{cm}^{3}$ above OHP; the maximum surface area is found above the North Sea. As the cold area is not overlaying the vortex, but is rather centred on the edge of the vortex, PSCs process chemically, not only polar vortex air, but also mid-latitude air.

In contrast to what happens in polar regions during winter, mid-latitude air is always exposed to sunlight. Thus, in these mid-latitude air masses, chlorine activation through heterogeneous reactions on PSC particles leads to immediate ozone 
destruction. In order to determine the ozone loss directly associated with the PSC event, an ozone passive tracer is also implemented in the MIMOSA model. This tracer is initialized in the same way as the chemically active ozone, every $12 \mathrm{~h}$. It is then advected passively. The ozone field is subtracted to the tracer field to estimate the cumulative ozone loss over $12 \mathrm{~h}$ (Fig. 4). The model-calculated ozone loss peaks near the Northern Mediterranean sea, with an ozone loss rate of $35 \mathrm{ppb} /$ day over the $12 \mathrm{~h}$ prior to PSC detection. This value is comparable to the Arctic ozone loss rates derived in January 2005 by Streibel et al. (2005), when early ozone losses were caused by distortions of the polar vortex and parts of it being exposed to sunlight (Goutail et al., 2005). In our case, the ozone loss is not confined to the polar vortex air. Indeed, although the vortex edge is rather located over Southern Europe (Fig. 3), the ozone loss area extends down to North Africa, indicating that this PSC event could also have impacted the ozone budget in mid-latitude air.

\section{Discussion and conclusions}

Here, we report the first detection of a Polar Stratospheric Cloud (PSC) at mid-latitudes, over Southern Europe, in January 2006. To our knowledge, this event is the most southward PSC ever observed in the Northern hemisphere. This observation is the first PSC detection at OHP after 25 years of systematic lidar observations (200 nigths/year). ECMWF temperature analyses and temperatures along the backward trajectories indicate that stratospheric temperatures were anomalously cold over Europe during this period and that the PSC formed on the edge of the Arctic polar vortex. CTM calculations show that PSC chemical processing was accompanied with a significant simultaneous ozone reduction, within and outside the vortex, as chlorine activated air masses were advected to sunlight regions triggering ozone destruction. However, the overall effect of such events on stratospheric ozone is more complex. Indeed, a strong distortion of the polar vortex like the one reported here is usually associated with strong planetary wave activity. This enhanced wave activity favours the occurrence of major or sudden stratospheric warmings that weaken the vortex, enhance polar temperatures and ultimately reduce the potential for PSC formation later on.

While ozone is expected to recover this century, is this extremely unusual event of a mid-latitude PSC a precursor sign of the climate feedback on stratospheric ozone budget or a simple anecdotal phenomena, part of the natural variability? Low stratospheric ozone levels permit UV-B radiations to reach the ground over heavily populated regions of the Northern hemisphere. In the case of such events becoming more frequent, due to systematic circulation variations induced by climate change, the question of their potential impact on delaying ozone recovery will have to be addressed. (a)
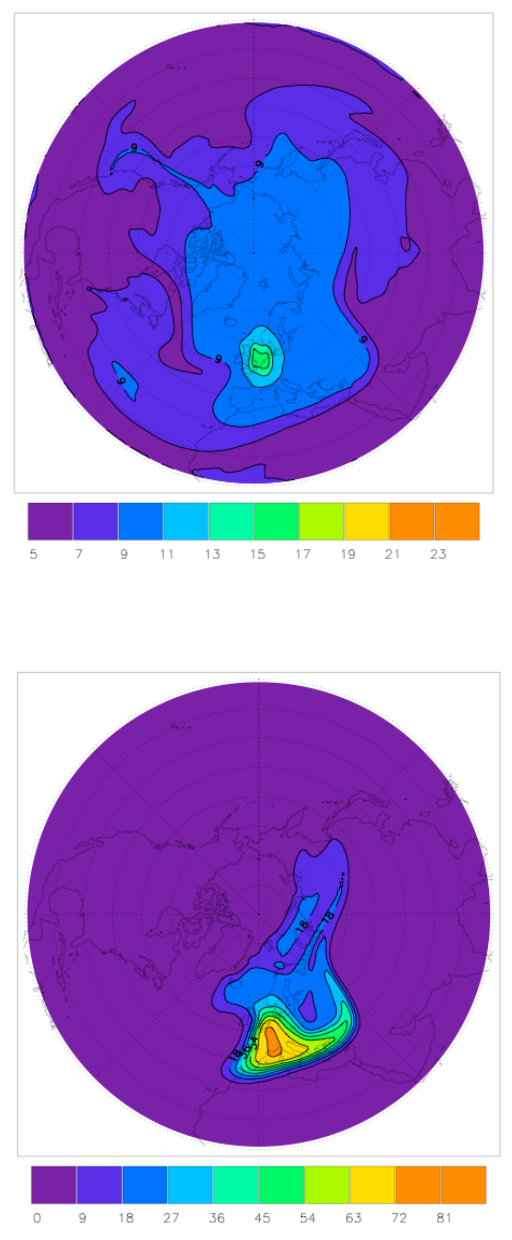

(b)

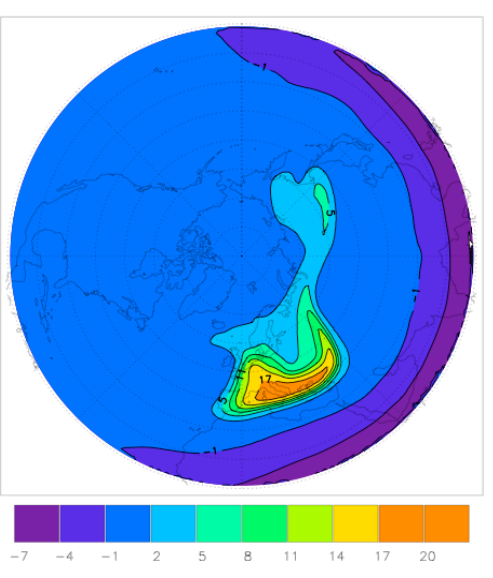

(c)

Fig. 4. Maps of PSC, Chlorine activation, and associated ozone loss estimated with numerical simulations. Model-calculated maps of (a) PSC surface area (in $10^{-9} \mathrm{~cm}^{2} / \mathrm{cm}^{3}$ ), (b) $\mathrm{ClO}_{\mathrm{x}} / \mathrm{Cl}_{\mathrm{y}}$ ratio (active Chlorine species $=\mathrm{Cl}, \mathrm{ClO}, \mathrm{Cl}_{2}, \mathrm{Cl}_{2} \mathrm{O}_{2}, \mathrm{HOCl}$ ) and (c) cumulative ozone loss (in ppb over the previous $12 \mathrm{~h}$ ) at $462 \mathrm{~K}$, on 19 January at 12:00 UT. 
Several observational and modelling studies (Ramaswamy et al., 2001; Shindell and Grewe, 2002; Rex et al., 2004) have demonstrated that stratospheric temperatures over polar regions could have decreased in the last decades in response to ozone depletion and to increases in greenhouse gases concentrations. However, the small expected changes of the mean winter temperature due to climate change is not directly related to the observed PSC formation because the temperature variability in the Arctic, is much larger than the long-term radiative contribution. PSC formation is in general rather related to the occurrence of cold events and the mean dynamical situation during the whole winter. In this case-study, the cold stratospheric temperatures were the result of a particular dynamical situation, i.e. the initial phase of a major stratospheric warming. During this initial phase of warming, very strong wave activity increases the baroclinic circulation in the Artic stratosphere. Adiabatic expansion of air that is lifted on one side of the polar vortex induces the development of an extremely cold region at the edge of the polar vortex, while temperatures warm up on the other side of the vortex, where air sinks. Dissipation of the wave then results in a strong poleward and downward motion of air over the whole Arctic, connected with strong warming everywhere. The outcome is a weak and warm vortex. The occurrence of such major stratospheric warming usually reduces or even terminates the conditions favourable for the Arctic polar vortex, limiting the overall amount of ozone that is destroyed during the Arctic winter. This was the case during this Arctic winter 2005/2006, which started with very cold temperatures and high chlorine activation, whereas the overall ozone loss was limited compared to previous winters of the last decade (F. Goutail, personal communication) because the ozone destruction was stopped by this early vortex breakdown and the concomitant increase in temperature. A weak and warm polar vortex was re-established later on and remained until the end of April. While low temperature can be generated further south during early winter, leading to direct ozone destruction, this destruction is limited. More importantly, this type of event decreases the chance of a long lasting ozone depletion during the rest of the winter. This PSC cloud led to a sporadic ozone loss over mid-latitude populated area early in the winter, but most probably minor implications on the ozone recovery.

Acknowledgements. Continuous lidar observations have been conducted within the Network of the Detection of Atmospheric Composition Changes with CNES, ADEME and INSU-CNRS funding. We acknowledge the support of the European Commission through GEOmon Integrated Project under the 6th Framework Program (contract number FP6-2005-Global-4-036677).

Edited by: B. Kärcher

\section{References}

Austin, J. and Wilson, R. J.: Ensemble simulations of the decline and recovery of stratospheric ozone, J. Geophys. Res., 111, D16314, doi:10.1029/2005JD006907, 2006.

Carslaw, K. S., Luo, B. P., Clegg, S. L., Peter, T., Brimblecombe, P., and Crutzen, P. J.: Stratospheric aerosol growth and $\mathrm{HNO}_{3}$ gas phase depletion from coupled $\mathrm{HNO}_{3}$ and water uptake by liquid particles, Geophys. Res. Lett., 21, 2479-2482, 1994.

Carter, R. D. and Bridge, G. C.: Stratospheric cirrosstratus over Scotland, Weather, 33, 309-318, 1978.

Charlton, A. J. and Polvani, L. M.: A new look at stratospheric sudden warmings I: climatology and modeling benchmarks, J. Climate, 20, 449-469, 2007.

Chazette, P., David, C., Lefrere, J., Godin, S., Pelon, J., and Mégie, G.: Comparative lidar study of the optical, geometrical, and dynamical properties of stratospheric post-volcanic aerosols, following the eruption of El Chichon and Mount Pinatubo, J. Geophys. Res., 100, 23 195-23 207, 1995.

Chipperfield, M. P., Feng, W., and Rex, M.: Arctic Ozone Loss and Climate Sensitivity: Updated Three-Dimensional Model Study, Geophys. Res. Lett., 32, L11813, doi:10.1029/2005GL022674, 2005.

Crutzen, P. J. and Arnold, F.: Nitric acid cloud formation in the cold Antarctic stratosphere: A major cause for the springtime "ozone hole", Nature, 324, 651-655, 1986.

David C., Godin, S., Mégie, G. , Emery, Y., and Flesia, C.: Physical state and composition of Polar Stratospheric Clouds inferred from airborne lidar measurements during SESAME, J. Atmos. Chem., 27, 1-16, 1997.

David, C., Bekki, S., Godin, S., Mégie, G., and Chipperfield, M. P.: Polar stratospheric clouds climatology over Dumont d'Urville between 1989 and 1993 and the influence of volcanic aerosols on their formation, J. Geophys., Res., 103, 22 163-22 180, 1998.

Goldfarb, L., Keckhut, P., Chanin, M. L., and Hauchecorne, A.: Cirrus climatological results from lidar measurements at $\mathrm{OHP}$ (44ํ N, $6^{\circ}$ E), Geophys. Res. Lett., 28, 9, 1687-1690, 2001.

Godin, S., Marchand, M., Hauchecorne, A., and Lefèvre, F.: Influence of Arctic polar ozone depletion on lower stratospheric ozone amounts at Haute-Provence Observatory $\left(43.92^{\circ} \mathrm{N}, \quad 5.71^{\circ} \mathrm{E}\right), \quad$ J. Geophys. Res., 107(D20), 8272 , doi:10.1029/2001JD000516, 2002,

Goutail F., Pommereau, J. P., Lefèvre, F., van Roozendael, M. , Andersen, S. B., Kastab Hoistar, B. A., Dorokhov, V., Kyrö, E., Chipperfield, M. P., and Feng, W.: Early unusual ozone loss during the Arctic winter 2002/2003 compared to other winters, Atmos. Chem. Phys., 5, 665-677, 2005, http://www.atmos-chem-phys.net/5/665/2005/.

Hanson D. R. and Mauersberger, K.: Laboratory studies of the nitric acid trihydrate: Implication for south polar stratosphere, Geophys. Res. Lett., 15, 855-858, 1988.

Hauchecorne, A., Godin, S., Marchand, M., Heese, B., and Souprayen, C.: Quantification of the transport of chemical constituents from the polar vortex to middle latitudes in the lower stratosphere using the high-resolution advection model MIMOSA and effective diffusivity, J. Geophys. Res., 107(D20), 8289, doi:10.1029/2001JD000491, 2002.

Hervig, M.: Stratospheric clouds over England, Geophys. Res. Lett., 26, 1137-1140, 1999.

Höpfner M., Luo, B. P., Massoli, P., Cairo, F., Spang, R., Snels, 
M., Donfrancesco, G. D., Stiller, G., von Clarmann, T., Fischer, H., and Biermann, U. : Spectroscopic evidence for NAT, STS, and ice in MIPAS infrared limb emission measurements of polar stratospheric clouds, Atmos. Chem. Phys., 6, 1201-1219, 2006, http://www.atmos-chem-phys.net/6/1201/2006/.

Junge C. E., Changon, C. W., and Manson, J. E.: Stratospheric aerosols, J. Meteorol., 18, 81-108, 1961.

Keckhut, P., Borchi, F., Bekki, S., Hauchecorne, A., and SiLaouina, M.: Cirrus classification at mid-latitude from systematic lidar observations, J. Appl. Meteorol. Climatol., 45(2), 249-258, doi:10.1175/JAM2348.1, 2006.

Keckhut, P., Hauchecorne, A., Bekki, S., Colette, A., David, C., and Jumelet, J.: Indications of thin cirrus clouds in the stratosphere at mid-latitudes, Atmos. Chem. Phys., 5, 3407-3414, 2005, http://www.atmos-chem-phys.net/5/3407/2005/.

Lefèvre, F., Brasseur, G. P., Folkins, I., Smith, A. K., and Simon, P.: Chemistry of the 1991-1992 stratospheric winter: Threedimensional model simulations, J. Geophys. Res., 99, 81838195, 1994.

Marchand, M., Godin, S., Hauchecorne, A., Lefèvre, F., Bekki, S., and Chipperfield, M.: Influence of polar ozone loss on northern midlatitude regions estimated by a high-resolution chemistry transport model during winter 1999-2000, J. Geophys. Res., 108(D5), 8326, doi:10.1029/2001JD00906, 2003.

McCormick, M. P., Steele, H. M., Hamill, P., Chu, W. P., and Swissler, T. J.: Polar Stratospheric Clouds sightings by SAM II, J. Atmos. Sci., 39, 1387-1397, 1982.

Murray, F. W.: On the computation of saturation vapor pressure, J. Appl. Meteorol., 6, 203-204, 1967.

Poole, L. R. and McCormick, M. P.: Polar Stratospheric Clouds and the Antarctic ozone hole, J. Geophys. Res., 93, 8423-8430, 1989.

Ramaswamy V., Chanin, M. L., Angell, J., Barnett, J., Gaffen, D., Gelman, M., Keckhut, P., Kolshelkov, Y., Labitzke, K., Lin, J.-J. R., O’Neill, A., Nash, J., Randel, W., Rood, R., Shine, K., Shiotani, M., and Swinbank, R.: Stratospheric Temperature Changes: Observations And Model Simulations, Rev. Geophys., 39, 71-122, 2001.

Rex, M., Salawitch, R. J., von der Gathen, P., Harris, N. R. P. , Chipperfield, M. P., Naujokat, B.: Arctic ozone loss and climate change, Geophys. Res. Lett., 31, L04116, doi:10.1029/2003GL018844, 2004.
Russell, P. B., Swissler, T. J., and McCormick, M. P.: Methodology for error analysis and simulation of lidar aerosol measurements, Appl. Opt., 18, 3783-3797, 1979.

Shindell, D. T. and Grewe, V.: Separating the influence of halogen and climate changes on ozone recovery in the upper stratosphere, J. Geophys. Res., 107(D12), ACL-3 doi:10.1029/2001JD000420, 2002.

Stohl, A., Hittenberger, M., and Wotawa, G.: Validation of the Lagrangian particle dispersion model FLEXPART against large scale tracer experiment data, Atmos. Environ., 24 4245-24 4264, 1998.

Streibel M., Rex, M., von der Gathen, P., Lehmann, R., Harris, N. R. P., Braathen, G. O., Reimer, E., Deckelmann, H., Chipperfield, M., Millard, G., Allaart, M., Andersen, S. B., Claude, H., Davies, J., De Backer, H., Dier, H., Dorokov, V., Fast, H., Gerding, M., Kyrö, E., Litynska, Z., Moore, D., Moran, E., Nagai, T., Nakane, H., Parrondo, C., Skrivankova, P., Stübi, R., Vaughan, G., Viatte, P., and Yushkov, V.: Chemical ozone loss in the Arctic winter 2002/2003 determined with Match, Atmos. Chem. Phys., 5, 4311-4333, 2005, http://www.atmos-chem-phys.net/5/4311/2005/.

Tabazadeh, A., Turco, R. P., and Jacobson, M. Z.: A model for studying the composition and chemical effects of stratospheric aerosols, J. Geophys. Res., 99, 12 897-12 914, 1994.

Toon, O. B., Browell, E. V., Kinne, S., and Jordan, J.: An analysis of lidar observations of Polar Stratospheric Clouds, Geophys. Res. Lett., 17, 393-396, 1990.

Turco, R. P., Whitten, R. C., and Toon, O. B.: Stratospheric aerosols: Observation and theory, Rev. Geophys. Space Phys., 20(2), 233-279, 1982.

Turco, R. P., Toon, O. B., and Hamill, P.: Heterogeneous physicochemistry of polar ozone hole, J. Geophys. Res., 94, $16493-$ 16510, 1989.

Vaughan, G. and Wareing, D. P.: Stratospheric aerosol measurements by dual polarisation lidar, Atmos. Chem. Phys., 4, 24412447, 2004, http://www.atmos-chem-phys.net/4/2441/2004/.

World Meteorological Organization, Scientific Assessment of Ozone Depletion: 1998, Global Ozone Research and Monitoring Project, Report No. 44, Geneva, 1999. 